\title{
CFD Analysis of a Propeller Flow and Cavitation
}

\author{
S. Subhas \\ PG student \\ NITW
}

\author{
V F Saji \\ Scientist ' $C$ ' \\ N S T L \\ Visakhapatnam
}

\author{
S. Ramakrishna \\ GVP College of \\ Engineering $(A)$ \\ Visakhapatnam
}

\author{
H. N Das \\ Scientist ' $F$ ' \\ N S T L \\ Visakhapatnam
}

\begin{abstract}
The propeller is the predominant propulsion device used in ships. The performance of propeller is conventionally represented in terms of non-dimensional coefficients, i.e., thrust coefficient $\left(\mathrm{K}_{\mathrm{T}}\right)$, torque coefficient $\left(\mathrm{K}_{\mathrm{Q}}\right)$ and efficiency and their variation with advance coefficients $(\mathrm{J})$. It is difficult to determine the characteristics of a full-size propeller in open water by varying the speed of the advance and the revolution rate over a range and measuring the thrust and torque of the propeller. Therefore, recourse is made to experiments with models of the propeller and the ship in which the thrust and torque of the model propeller can be conveniently measured over a range of speed of advance and revolution rate.
\end{abstract}

Experiments are very expensive and time consuming, so the present paper deals with a complete computational solution for the flow using Fluent 6.3 software. When the operating pressure was lowered below the vapor pressure of surrounding liquid it simulates cavitating condition. In the present work, Fluent 6.3 software is also used to solve advanced phenomena like cavitation of propeller. The simulation results of cavitation and open water characteristics of propeller are compared with experimental predictions, as obtained from literature [1].

\section{Keywords}

Propeller, CFD, Cavitation, Large Eddy Simulation, Multi phase flows, Open water characteristics, Validation

\section{INTRODUCTION}

A marine propeller is normally fitted to the stern of the ship where it operates in water that has been disturbed by the ship as it moves ahead. A propeller that revolves in the clockwise direction (viewed from aft) when propelling the ship forward is called a right hand propeller. When a propeller is moved rapidly in the water then the pressure in the liquid adjacent to body drops in proportion to the square of local flow velocity. If the local pressure drops below the vapor pressure of surrounding liquid, small pockets or cavities of vapor are formed. Then the flow slows down behind the object and these little cavities are collapsed with very high explosive force. If the cavitation area is sufficiently large, it will change the propeller characteristics such as decrease in thrust, alteration of torque, damage of propeller material (corrosion and erosion) and strong vibration excitation and noise.

During recent year's great advancement of computer performance, Computational Fluid-Dynamics (CFD) methods for solving the Reynolds Averaged Navier-Stokes (RANS) equation have been increasingly applied to various marine propeller geometries. While these studies have shown great advancement in the technology, some issues still need to be addressed for more practicable procedures. These include mesh generation strategies and turbulence model selection. With the availability of superior hardware, it becomes possible to model the complex fluid flow problems like propeller flow and cavitation.

For many years, propellers were predicted using the liftingline theory, where the blade was represented by a vortex line and the wake by a system of helicoidal vortices. With the advent of computers, numerical methods developed rapidly from the 1960s onwards. The first numerical methods were based on the lifting line theory, and later the lifting surface model was developed. Salvatore et al. [1] presented the theoretical basis of the lifting-line theory based on perturbation methods. Chang [2] applied a finite volume CFD method in conjuction with the standard $\mathrm{k}-\varepsilon$ turbulence model to calculate the flow pattern and performance parameters of a DTNSRDC P4119 marine propeller in a uniform flow.

Sanchez-Caja [3] has calculated open water flow patterns and performance coefficients for DTRC 4119 propeller using FINFLO code. The flow patterns were generally predicted with the $\mathrm{k}-\varepsilon$ turbulent model. He has suggested a better prediction of the tip vortex flow, which requires a more sophisticated turbulence model. Bernad [4] presented a numerical investigation of cavitating flows using the mixture model implemented in the Fluent 6.2 commercial code. Senocak et al. [5] presented a numerical simulation of turbulent flows with sheet cavitation. Sridhar et al. [6] predicted the frictional resistance offered to a ship in motion using Fluent 6.0 and these results are validated by experimental results.

Salvatore et al. [7] performed computational analysis by using the INSEAN-PFC propeller flow code developed by CNRINSEAN. Experiments are carried to know the open water performance, evaluation of velocity field in the propeller wake and prediction of cavitation in uniform flow conditions. Bertetta et al. [8] presented an experimental and numerical analysis of unconventional CLT propeller.Two different numerical approaches, a potential panel method and RANSE solver, are employed. Zhi-feng and Shi-liang [9] studied the cavitation performance of propellers using viscous multiphase flow theories and with a hybrid grid based on Navier-Stokes and bubble dynamics equations. Pereira et al. [10] presented an experimental and theoretical investigation on a cavitating propeller in uniform inflow. Flow field investigations by advanced imaging techniques are used to extract quantitative information on the cavity extension. Pereira and Sequeira [11] developed turbulent vorticity-confinement strategy for RANSbased industrial propeller-flow simulations. The methodology aims at an improved prediction of tip vortices, which are an origin of cavitation.

The numerical or experimental analysis and comparison of results highlight the peculiarities of propellers, the possibility to increase efficiency and reduce cavitation risk, in order to exploit the design approaches already well proven for conventional propellers also in the case of unconventional geometries. The simulated flow pattern agrees with the 
experimental data in most cases. However, the detailed shape of the wake behind the propeller blades is not captured. The present methodologies give in local disagreement with the experimental data, especially around blade wake and tip vortex. However, in order to clear the reason of these disagreements, more study using other turbulence models or other mesh patterns is necessary.

So in the present paper, the CFD code Fluent 6.3 software is used to solve advanced phenomena like cavitation of propeller. The investigation is based on standard $\mathrm{K}-\mathrm{C}$ turbulence model in combination with a volume of fluid implementation to capture the interface between liquid and vapour. The open water characteristics of a propeller are estimated in terms of the advance coefficient $\mathrm{J}$, the thrust coefficient $\mathrm{K}_{\mathrm{T}}$, the torque coefficient $\mathrm{K}_{\mathrm{Q}}$ and the open water efficiency $\eta_{0}$ in both non cavitating and cavitating condition of propeller. The simulation results of cavitation and open water characteristics of propeller are compared with experimental predictions, as obtained from literature [1].

\section{GEOMETRIC MODELING}

Geometric modeling of propeller is carried out using CATIA V5R20. The non-dimensional geometry data of the propeller is presented in Tables $1 \&$ 2.This data was converted into point co-ordinate data to generate the expanded sections, these sections stacked according to their radial distance along stack line as shown in Fig. 1, these sections were rotated according to pitch angle. Finally wrapped around respective cylindrical diameters to get the final sections as shown in Fig. 2 and these sections were connected smoothly by lofted surfaces. Table 1 shows dimensions of the INSEAN E779a model propeller used in present flow and cavitation simulations using Fluent 6.3. Table 2 shows the blade characteristics of the INSEAN E779a model propeller used to generate the surface model of propeller using CATIA V5R20.

Table 1. Dimensions of the INSEAN E779a model propeller

\begin{tabular}{|l|l|}
\hline Propeller Diameter & $\mathrm{D}_{\mathrm{p}}=227.27 \mathrm{~mm}$ \\
\hline Number of blades & $\mathrm{Z}=4$ \\
\hline Pitch ratio(nominal) & $\mathrm{P} / \mathrm{D}_{\mathrm{p}}=1.1$ \\
\hline Skew angle at blade tip & $\theta^{\text {tip }}=4^{0} 48^{\prime}$ (positive) \\
\hline Rake (nominal) & $\mathrm{I}=4^{0} 35^{\prime}$ (forward) \\
\hline Expanded area ratio & $\mathrm{EAR}=0.689$ \\
\hline Hub diameter (at prop. Ref. line) & $\mathrm{D}_{\mathrm{H}=45.53 \mathrm{~mm}}$ \\
\hline Hub length & $\mathrm{L}_{\mathrm{H}}=68.30 \mathrm{~mm}$ \\
\hline
\end{tabular}

Table 2. Blade characteristics of the INSEAN E779a model propeller

\begin{tabular}{|c|c|c|c|c|c|c|}
\hline $\mathrm{r} / \mathrm{R}_{\mathrm{p}}$ & $\mathrm{P} / \mathrm{D}_{\mathrm{p}}$ & $\mathrm{c} / \mathrm{D}_{\mathrm{p}}$ & $\mathrm{X}_{\mathrm{LE}} / \mathrm{D}_{\mathrm{p}}$ & $\mathrm{T}_{\max /} \mathrm{D}_{\mathrm{p}}$ & $\mathrm{x}_{\mathrm{Tmax}} / \mathrm{c}$ & rake/D $\mathrm{D}_{\mathrm{p}}$ \\
\hline $\begin{array}{l}0.26 \\
40\end{array}$ & $\begin{array}{l}1.111 \\
79\end{array}$ & $\begin{array}{l}0.278 \\
38\end{array}$ & $\begin{array}{l}0.160 \\
44\end{array}$ & $\begin{array}{l}0.044 \\
033\end{array}$ & $\begin{array}{l}0.176 \\
33\end{array}$ & $\begin{array}{l}+0.006 \\
01\end{array}$ \\
\hline $\begin{array}{l}0.35 \\
20\end{array}$ & $\begin{array}{l}1.120 \\
39\end{array}$ & $\begin{array}{l}0.307 \\
99\end{array}$ & $\begin{array}{l}0.170 \\
83\end{array}$ & $\begin{array}{l}0.031 \\
24\end{array}$ & $\begin{array}{l}0.014 \\
066\end{array}$ & $\begin{array}{l}-0.010 \\
72\end{array}$ \\
\hline $\begin{array}{l}0.44 \\
00\end{array}$ & $\begin{array}{l}1.120 \\
21\end{array}$ & $\begin{array}{l}0.335 \\
71\end{array}$ & $\begin{array}{l}0.180 \\
19\end{array}$ & $\begin{array}{l}0.025 \\
65\end{array}$ & $\begin{array}{l}0.086 \\
74\end{array}$ & $\begin{array}{l}-0.014 \\
37\end{array}$ \\
\hline $\begin{array}{l}0.52 \\
80\end{array}$ & $\begin{array}{l}1.116 \\
71\end{array}$ & $\begin{array}{l}0.360 \\
01\end{array}$ & $\begin{array}{l}0.187 \\
18\end{array}$ & $\begin{array}{l}0.021 \\
19\end{array}$ & $\begin{array}{l}0.069 \\
93\end{array}$ & $\begin{array}{l}-0.0117 \\
94\end{array}$ \\
\hline $\begin{array}{l}0.61 \\
60\end{array}$ & $\begin{array}{l}1.114 \\
67\end{array}$ & $\begin{array}{l}0.376 \\
66\end{array}$ & $\begin{array}{l}0.189 \\
66\end{array}$ & $\begin{array}{l}0.016 \\
72\end{array}$ & $\begin{array}{l}0.103 \\
53\end{array}$ & $\begin{array}{l}-0.021 \\
58\end{array}$ \\
\hline $\begin{array}{l}0.70 \\
40\end{array}$ & $\begin{array}{l}1.117 \\
28\end{array}$ & $\begin{array}{l}0.378 \\
41\end{array}$ & $\begin{array}{l}0.184 \\
89\end{array}$ & $\begin{array}{l}0.012 \\
93\end{array}$ & $\begin{array}{l}0.058 \\
60\end{array}$ & $\begin{array}{l}-0.025 \\
01\end{array}$ \\
\hline $\begin{array}{l}0.79 \\
20\end{array}$ & $\begin{array}{l}1.117 \\
38\end{array}$ & $\begin{array}{l}0.363 \\
35\end{array}$ & $\begin{array}{l}0.169 \\
54\end{array}$ & $\begin{array}{l}0.009 \\
67\end{array}$ & $\begin{array}{l}0.016 \\
61\end{array}$ & $\begin{array}{l}-0.028 \\
76\end{array}$ \\
\hline $\begin{array}{l}0.88 \\
0\end{array}$ & $\begin{array}{l}1.110 \\
24\end{array}$ & $\begin{array}{l}0.317 \\
04\end{array}$ & $\begin{array}{l}0.134 \\
51\end{array}$ & $\begin{array}{l}0.006 \\
26\end{array}$ & $\begin{array}{l}-0.07 \\
573\end{array}$ & $\begin{array}{l}-0.032 \\
67\end{array}$ \\
\hline $\begin{array}{l}0.96 \\
80\end{array}$ & $\begin{array}{l}1.110 \\
89\end{array}$ & $\begin{array}{l}0.191 \\
74\end{array}$ & $\begin{array}{l}0.059 \\
74\end{array}$ & $\begin{array}{l}0.003 \\
88\end{array}$ & $\begin{array}{l}-.018 \\
842\end{array}$ & $\begin{array}{l}-0.036 \\
44\end{array}$ \\
\hline $\begin{array}{l}0.99 \\
00\end{array}$ & $\begin{array}{l}1.110 \\
12\end{array}$ & $\begin{array}{l}0.115 \\
74\end{array}$ & $\begin{array}{l}0.016 \\
21\end{array}$ & $\begin{array}{l}0.003 \\
28\end{array}$ & $\begin{array}{l}-0.45 \\
992\end{array}$ & $\begin{array}{l}-0.037 \\
56\end{array}$ \\
\hline $\begin{array}{l}0.99 \\
88\end{array}$ & $\begin{array}{l}1.110 \\
12\end{array}$ & $\begin{array}{l}0.049 \\
06\end{array}$ & $\begin{array}{l}-0.02 \\
073\end{array}$ & $\begin{array}{l}0.001 \\
85\end{array}$ & $\begin{array}{l}-0.97 \\
258\end{array}$ & $\begin{array}{l}-0.038 \\
35\end{array}$ \\
\hline
\end{tabular}

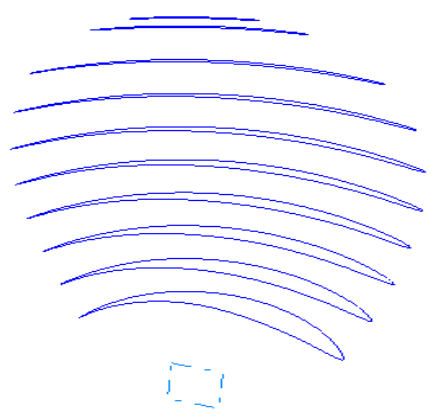

Fig 1: Stacking section

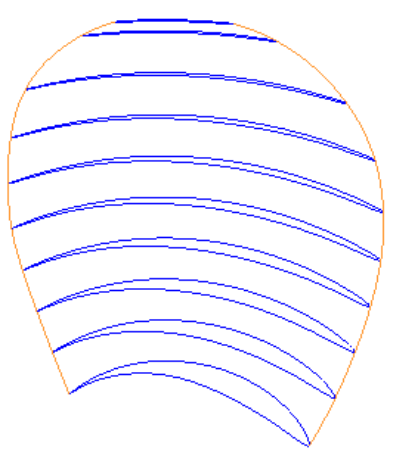

Fig 2: Wrapped sections 


\section{GRID GENERATION}

The flow domain is required to be descritized to convert the partial differential equations into series of algebraic equations. This process is called grid generation. A solid model of the propeller was created in CATIA V5R20 as a first step of grid generation. The complexity of the blade and complete domain is shown in Fig. 3.

To generate the structural grid with hexahedral cells commercially available grid generation code ICEM CFD was used. The inlet was considered at a distance of 3D (where D is diameter of the propeller) from mid of the chord of the root section. Outlet is considered at a distance of $4 \mathrm{D}$ from same point at downstream. In radial direction domain was considered up to a distance of 4D from the axis of the hub. This peripheral plane is called far-field boundary. The mesh was generated in such a way that cell sizes near the blade wall were small and increased towards outer boundary. Fig. 4 and Fig. 5 shows the grid over the entire domain and propeller used for flow and cavitaton simulations using Fluent 6.3.

After convergence total number of cells generated for entire grid was 1.3 million. The four blades are at a regular angular interval of 90 degrees. So modeling of one angular sector with an extent of 90 degrees containing one propeller blade is sufficient to solve the entire flow domain. The effect of other blades was taken care by imposing periodic boundary condition on meridional planes at the two sides. Fig. 6 shows grid over the single propeller blade, Fig. 7 shows the grid over the surface of the blade and hub and Fig. 8 shows grid near the propeller surface. It is clearly shows that denser mesh is near propeller surface to capture the flow properties with significant quality.

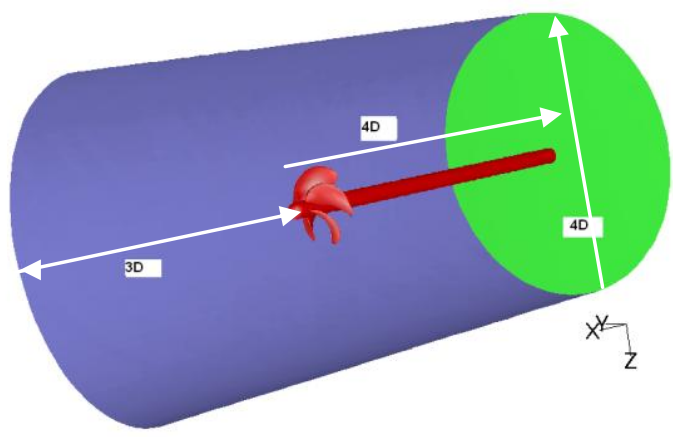

Fig 3: Domain for full propeller simulations

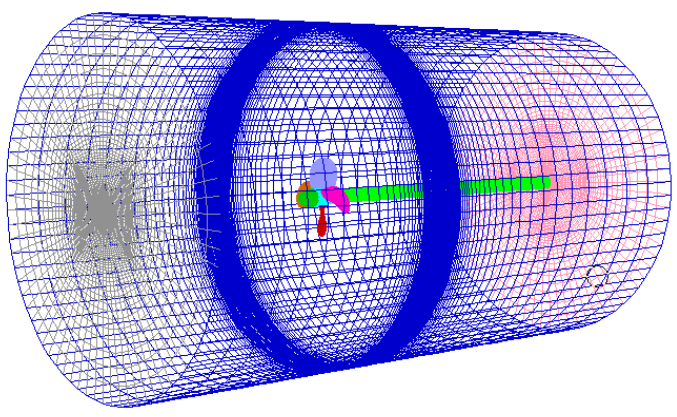

Fig 4: Grid over the entire domain

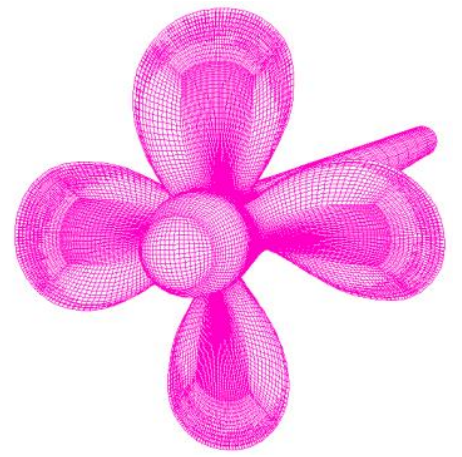

Fig 5: Grid over the propeller

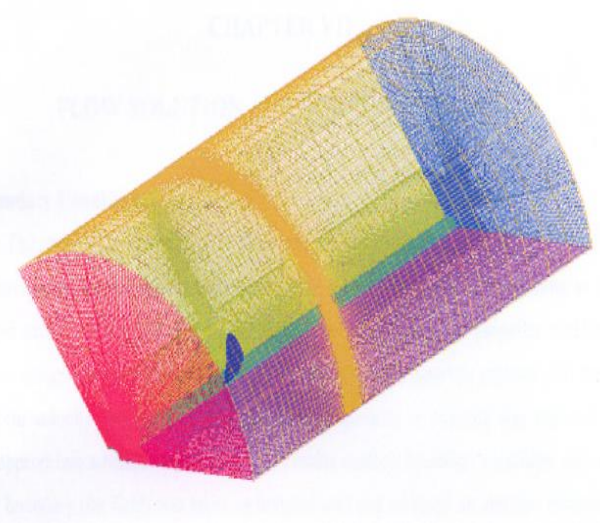

Fig 6: Grid over the single propeller blade

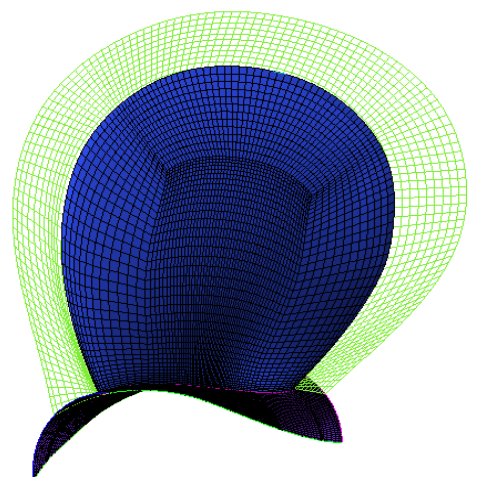

(a)

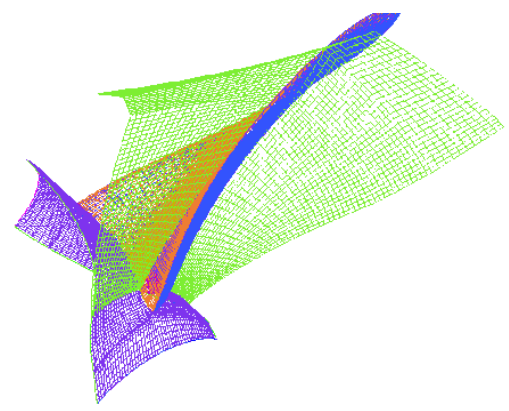

(b)

Fig 7: Grid over the surface of the (a) blade and (b) hub 


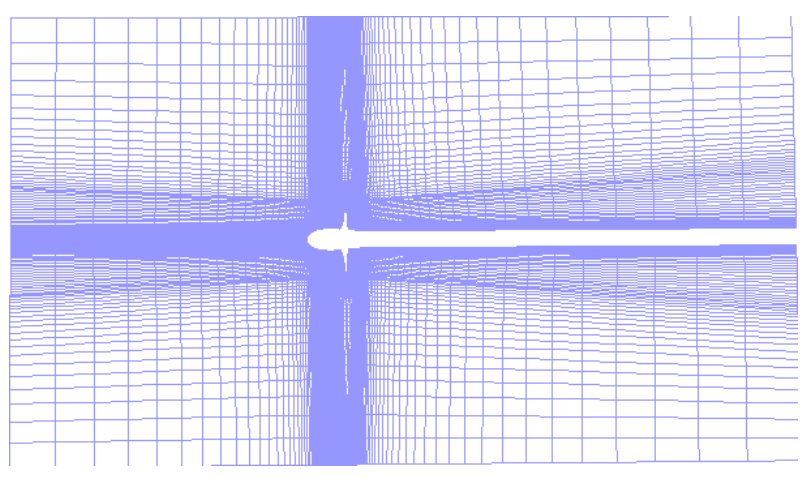

Fig 8: Grid near the propeller surface

\section{SOLUTION AND SOLVER SETTINGS}

\subsection{Boundary Conditions}

The continuum was chosen as fluid and the properties of water were assigned to it. A moving reference frame is assigned to fluid with a rotational velocity (1500rpm, 1800rpm, 2400rpm and 3000rpm). The wall forming the propeller blade and hub were assigned a relative rotational velocity of zero with respect to adjacent cell zone. A uniform velocity $6.22 \mathrm{~m} / \mathrm{sec}$ was prescribed at inlet. At outlet outflow boundary condition was set. The far boundary (far field) was taken as inviscid wall and assigned an absolute rotational velocity of zero. Fig. 9 shows the boundary conditions imposed on the propeller domain.

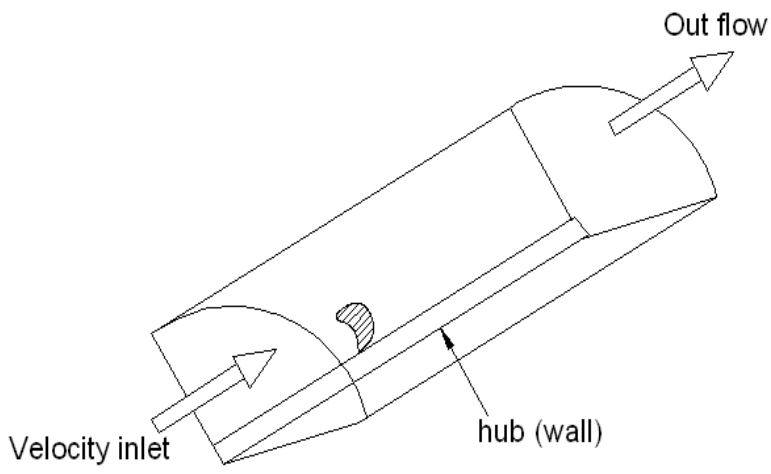

(a)

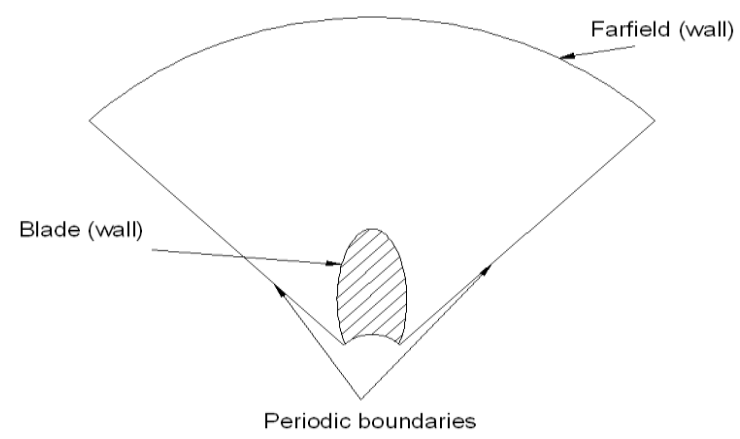

(b)

Fig 9: Boundary Conditions on propeller domain (a) 3D view (b) Front view

\subsection{Flow Solution and Solver Settings}

The CFD code Fluent 6.3 was used to solve the three dimensional viscous incompressible flow. The parallel version of Fluent 6.3 simultaneously computes the flow equations using multiple processors. The software can automaticallypartition the grid into sub-domains, to distribute the computational job between available numbers of processors. Table 3 shows the propeller domain details. Table 4 and Table 5 shows the details of non cavitating and cavitating details of the flow respectively.

Table 3. Propeller Details

\begin{tabular}{|l|l|}
\hline Propeller & THE INSEAN E779a \\
\hline Principal Dimensions & Propeller Diameter $=0.227 \mathrm{~m}$ \\
\hline Domain size & $\begin{array}{l}\text { Cylindrical domain of } \\
\text { Length }=1.75 \mathrm{~m}, \\
\text { Diameter }=0.97 \mathrm{~m} .\end{array}$ \\
\hline Mesh count & 1.30 million Hexahedral cells. \\
\hline
\end{tabular}

Table 4. Details of non Cavitating flow

\begin{tabular}{|l|l|}
\hline Pressure Link & SIMPLE \\
\hline Pressure & Standard \\
\hline $\begin{array}{c}\text { Descretisation scheme for } \\
\text { convective fluxes and } \\
\text { turbulence parameters }\end{array}$ & Quadratic Upwind (QUICK) \\
\hline Turbulence model & Standard K-C \\
\hline Near Wall Treatment & Standard wall functions \\
\hline Solver & Steady \\
\hline
\end{tabular}

Table 5. Details of Cavitating flow

\begin{tabular}{|l|l|}
\hline Pressure Link & SIMPLE \\
\hline Pressure & Standard \\
\hline $\begin{array}{l}\text { Descretisation scheme } \\
\text { for convective fluxes } \\
\text { and turbulence parameters }\end{array}$ & First Order Upwind \\
\hline Turbulence model & Standard K- $C$ \\
\hline Near Wall Treatment & Standard wall functions \\
\hline Models & Multiphase $\rightarrow$ Mixture \\
\hline Phases & \multicolumn{1}{|c|}{ Water } \\
\hline Solver & Water Vapor \\
\hline Operating pressure & $90000 \mathrm{~N} / \mathrm{m}^{2}$ \\
\hline Vapor pressure & $5000 \mathrm{~N} / \mathrm{m}^{2}$ \\
\hline
\end{tabular}




\section{RESULTS AND DISCUSSION}

\subsection{Propeller under Non-Cavitation}

The performance of propeller is conventionally represented in terms of non-dimensional coefficients, i.e., thrust coefficient $\left(\mathrm{K}_{\mathrm{T}}\right)$, torque coefficient $\left(\mathrm{K}_{\mathrm{Q}}\right)$ and efficiency and their variation with advance coefficients (J). A complete computational solution for the flow was obtained using Fluent 6.3 software. The software also estimated thrust and torque from the computational solutions for different rotational speeds (rps) of the propeller. These were expressed in terms of $\mathrm{K}_{\mathrm{T}} \& \mathrm{~K}_{\mathrm{Q}}$. The estimated thrust and torques are shown in Table 6 . Comparison of estimated non-dimensional coefficients and efficiency $(\eta)$ against experimental predictions, as obtained from literature [1], are shown in Table 7. Fig. 10 shows the comparison of predicted $\mathrm{KT} \& \mathrm{~K}_{\mathrm{Q}}$ with experimental data [1]. It shows that $\mathrm{K}_{\mathrm{T}}$ and $\mathrm{K}_{\mathrm{Q}}$ coefficients are decreasing with increasing of advance coefficients $(\mathrm{J})$. Maximum efficiency is observed at $\mathrm{J}=0.9$.

Table 6. Computational estimation of Thrust and Torque

\begin{tabular}{|c|c|c|c|c|}
\hline $\begin{array}{c}\text { Rotational } \\
\text { speed } \\
\mathrm{n}(\mathrm{rps})\end{array}$ & $\begin{array}{c}\text { Velocity } \\
\text { of } \\
\text { Advance } \\
\left(\mathrm{U}_{\infty}\right)\end{array}$ & $\begin{array}{c}\text { Advance } \\
\text { coefficient }(\mathrm{J})\end{array}$ & $\begin{array}{c}\text { Thrust } \\
\text { force }(\mathrm{T}) \\
\mathrm{N}\end{array}$ & $\begin{array}{c}\text { Torque } \\
(\mathrm{Q}) \\
\mathrm{N}-\mathrm{m}\end{array}$ \\
\hline 25 & 6.22 & 1.092511 & 57.9089 & 5.7258 \\
\hline 30 & 6.22 & 0.910426 & 322.7728 & 16.3267 \\
\hline 40 & 6.22 & 0.682819 & 1075.962 & 46.5109 \\
\hline 50 & 6.22 & 0.546256 & 2102.149 & 87.0225 \\
\hline
\end{tabular}

Table 7. Comparison of predicted and experimental values[1] of $K_{T}$ and $K_{Q}$

\begin{tabular}{|c|c|c|c|c|c|}
\hline \multirow{2}{*}{$\begin{array}{c}\text { Advance } \\
\text { Coefficient } \\
\text { (J) }\end{array}$} & \multicolumn{2}{|c|}{$\begin{array}{c}\text { Thrust } \\
\text { coefficient }\end{array}$} & \multicolumn{2}{|c|}{$\begin{array}{c}\text { Torque } \\
\text { coefficient }\end{array}$} & \multirow{2}{*}{$\begin{array}{c}\text { Efficiency } \\
\text { (CFD) }\end{array}$} \\
\hline & $\begin{array}{c}\mathrm{K}_{\mathrm{T}} \\
(\mathrm{CFD}\end{array}$ & $\begin{array}{c}\mathrm{K}_{\mathrm{T}} \\
\text { (Exp.) }\end{array}$ & $\begin{array}{c}\mathrm{K}_{\mathrm{Q}} \\
(\mathrm{CFD}\end{array}$ & $\begin{array}{c}\mathrm{K}_{\mathrm{Q}} \\
\text { (Exp.) }\end{array}$ & \\
\hline 1.092 & 0.034 & 0.03 & 0.152 & 0.16 & 0.399 \\
\hline 0.910 & 0.135 & 0.14 & 0.301 & 0.30 & 0.650 \\
\hline 0.682 & 0.253 & 0.24 & 0.483 & 0.48 & 0.570 \\
\hline 0.546 & 0.317 & 0.32 & 0.578 & 0.58 & 0.476 \\
\hline
\end{tabular}

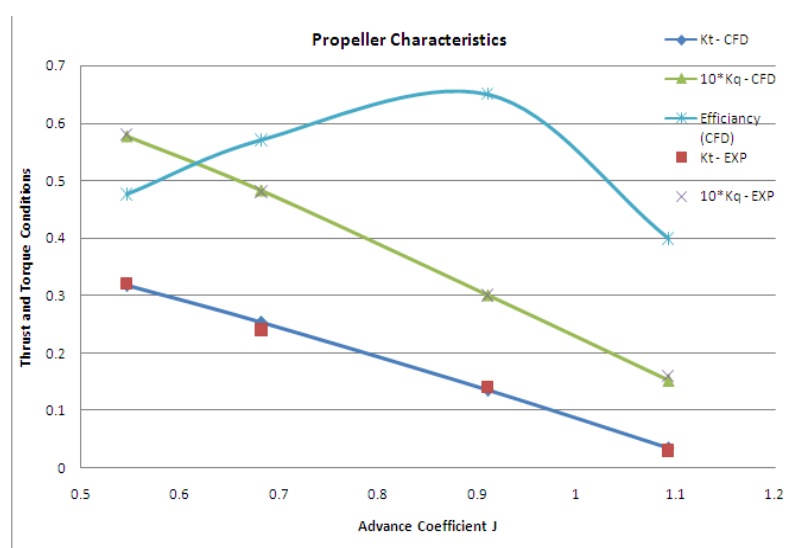

Fig. 10 Comparison of predicted $K_{T} \& K_{Q}$ with experimental data [1]
Fig. 11 and Fig. 12 shows the velocity vectors at $r / R_{p}=0.264$ for advance velocity $6.22 \mathrm{~m} / \mathrm{s}, 50 \mathrm{rps}, \mathrm{J}=0.546$ and velocity vectors at $r / R_{p}=0.704$ for advance velocity $6.22 \mathrm{~m} / \mathrm{s}, 50 \mathrm{rps}$, $\mathrm{J}=0.546$ respectively. From the two figures it is clearly observed that there is no flow separation near the blade surface at every radial section, which was expected as the propeller was a well designed standard one.

Fig. 13 and Fig. 14 show the pressure distribution on surface of impeller blades in terms of pressure coefficient at advance velocity $6.22 \mathrm{~m} / \mathrm{s}$, rotational speed $50 \mathrm{rps} \&$ advance coefficient $\mathrm{J}=0.546$ and at advance velocity $6.22 \mathrm{~m} / \mathrm{s}$, rotational speed 50rps \& advance coefficient $\mathrm{J}=0.901$ respectively. The face and back are experiencing high pressure and low pressure respectively. However when propeller was operating at very low rpm it is not able to generate thrust, so a reverse trend in pressure was observed. This explains the development of thrust by propeller at high rotations whereas the propeller is contributing to resistance. It is evident that there is a concentration of high-pressure region near the leading edge of the propeller.

Fig. 15 and Fig. 16 shows the graph between the pressure coefficient and position indicates the pressure distribution on the blade at $J=1.095, r / R_{p}=0.264$ and $J=1.095, r / R_{p}=0.704$ respectively. From the two graphs it is noted that as $r / R_{p}$ is increasing, i.e., moving towards the tip, larger portion of back surface of the blade experiences low pressure. So contribution of this part of the blade is more towards the total development of the thrust. The path lines emanating from the downstream of propeller are shown in Fig. 17, which indicates the swirling path followed by fluid particles in downstream of the propeller in axial direction. This illustrates the flow pattern behind the propeller.

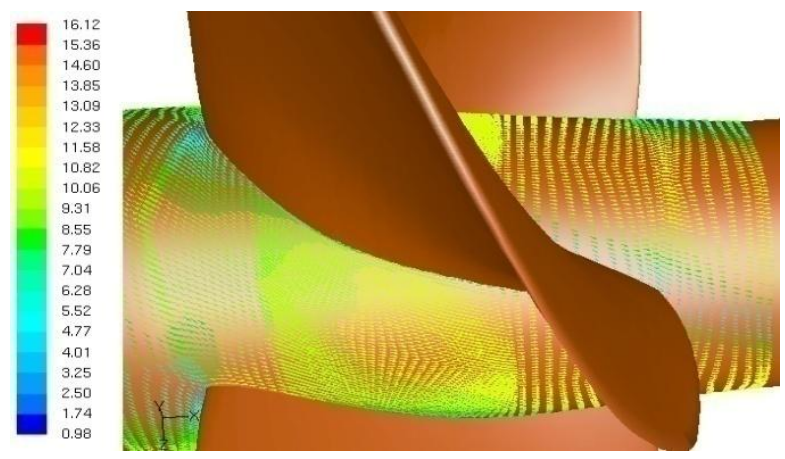

Fig 11: Velocity vectors at $r / R_{p}=0.264$ for advance velocity $6.22 \mathrm{~m} / \mathrm{s}, 50 \mathrm{rps}, \mathrm{J}=0.546$

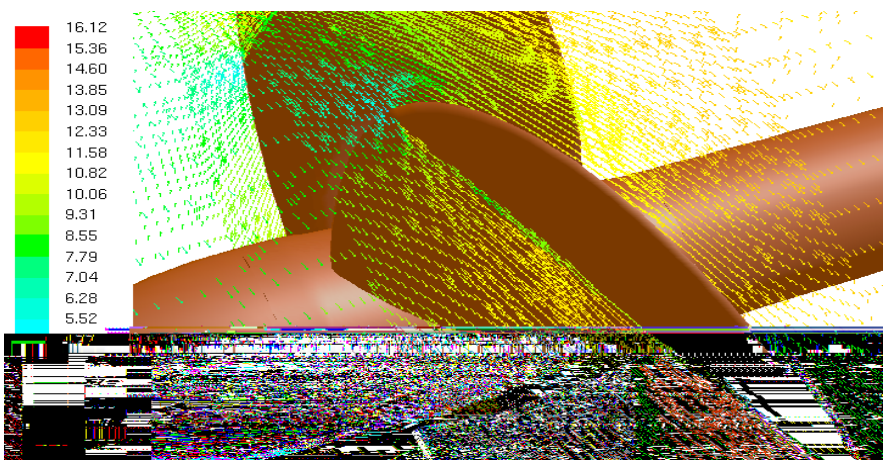

Fig. 12: Velocity vectors at $r / R_{p}=0.704$ for Advance velocity $=6.22 \mathrm{~m} / \mathrm{s}, 50 \mathrm{rps}, \mathrm{J}=0.546$ 

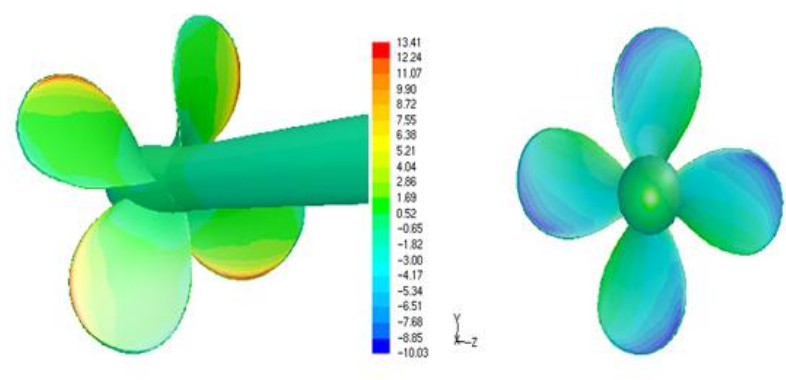

Contours of Pressure Coefficient

Fig. 13: Pressure distribution on the surface of the blades in terms of pressure coefficient at advance velocity $6.22 \mathrm{~m} / \mathrm{s}$, rotational speed 50rps $\&$ advance coefficient $\mathrm{J}=\mathbf{0 . 5 4 6}$

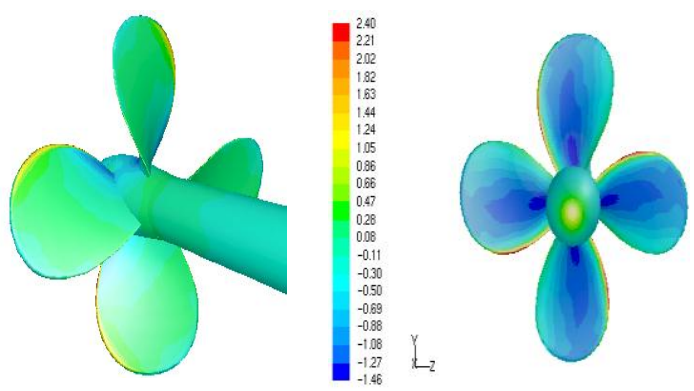

Fig. 14: Pressure distribution on the surface of the blades in terms of pressure coefficient at advance velocity $6.22 \mathrm{~m} / \mathrm{s}$, rotational speed 50rps \& advance coefficient $\mathbf{J}=\mathbf{0 . 9 0 1}$

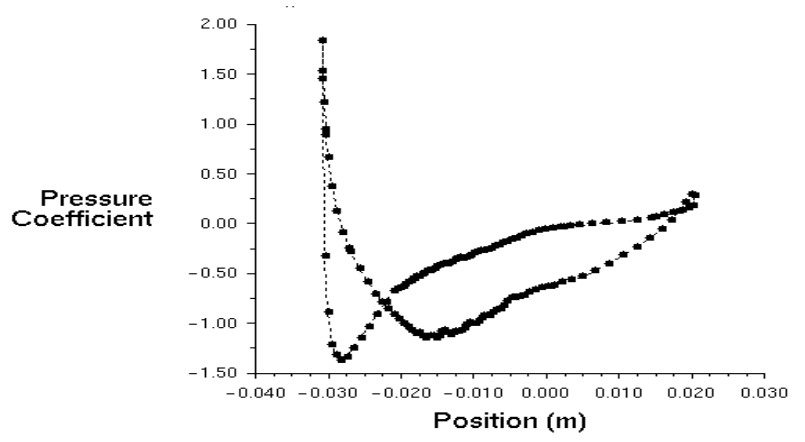

Fig 15: Pressure distribution graph at $\mathrm{J}=\mathbf{1 . 0 9 5}$ and $\mathrm{r} / \mathrm{R}_{\mathrm{p}}=\mathbf{0 . 2 6 4}$

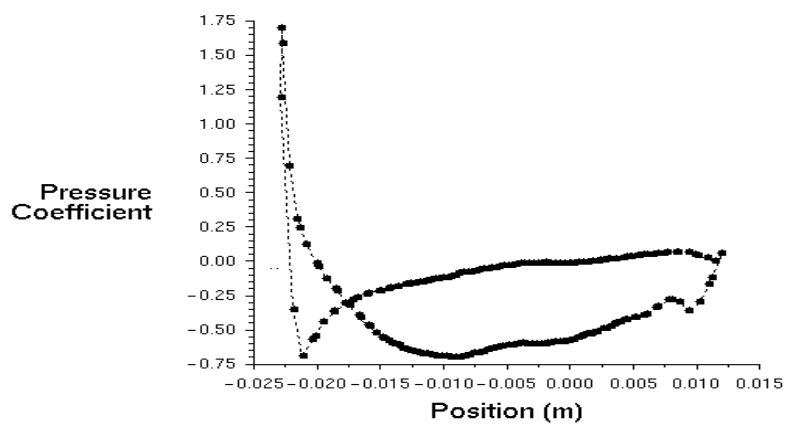

Fig 16: Pressure distribution graph at $\mathrm{J}=\mathbf{1 . 0 9 5}$ and $\mathrm{r} / \mathrm{R}_{\mathrm{p}}=\mathbf{0 . 7 0 4}$

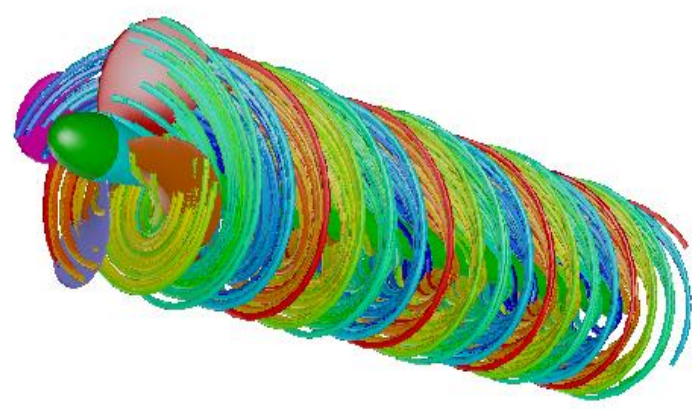

Fig 17: Path Lines at downstream of propeller

\subsection{Propeller under Cavitation}

When the operating pressure was lowered below the vapor pressure of surrounding liquid it simulates cavitating condition. In this condition two phases, water and water vapour are considered in simulations with Fluent 6.3. Table 8 shows the comparison between the performance of the propeller in cavitating and non-cavitating conditions. The cavitation number for this cavitating condition is 2.07 , which is fairly high, and so the propeller is marginally cavitating and not heavily cavitating. Because of this only a small drop in thrust coefficient was observed in Table 8 , when the torque demand was increased slightly.

Table 8. Comparison between the performance of the propeller in cavitating and non-cavitating condition

\begin{tabular}{|c|c|c|c|}
\hline Condition & $\begin{array}{c}\text { Advance } \\
\text { coefficient } \\
(\mathrm{J})\end{array}$ & $\begin{array}{c}\text { Thrust } \\
\text { Coefficient } \\
\left(\mathrm{K}_{\mathrm{T}}\right)\end{array}$ & $\begin{array}{c}\text { Torque } \\
\text { Coefficient } \\
\left(\mathrm{K}_{\mathrm{Q}}\right)\end{array}$ \\
\hline $\begin{array}{c}\text { Non } \\
\text { Cavitating }\end{array}$ & 0.846908 & 0.169183 & 0.0352437 \\
\hline Cavitating & 0.846908 & 0.168778 & 0.0366621 \\
\hline
\end{tabular}

Fig. 18 and Fig. 19 shows the graph between the pressure coefficient and position indicates the pressure distribution on the blade at $\mathrm{J}=0.847, \mathrm{r} / \mathrm{R}_{\mathrm{p}}=0.264$ and $\mathrm{J}=0.847, \mathrm{r} / \mathrm{R}_{\mathrm{p}}=0.880$ respectively under cavitating condition. Fig. 20 shows the contour of pressure coefficient in cavitation condition. When compared with pressure in distribution under non-cavitating conditions in Fig. 15 and Fig. 16, it is slightly increased in cavitating condition as shown in Fig. 18 and Fig. 19. The pressure is expected to remain constant over the cavitating part of the blade. But some change in pressure distribution is observed when propeller started cavitating. However, the phenomenon of constant pressure in the cavitating region was not observed clearly in the Fig. 18 and Fig. 19. This may be because of the fact that cavitation has just initiated or the computational solution could not capture the phenomenon properly. Fig. 21 shows the contour of volume fraction under cavitation condition. From this it is observed that the volume fraction is varying from 0.71 to 1.0 . Fig. 22 shows the development of cavities on propeller blade and comparison between CFD and experiments [1]. It clearly shows that water got vaporized in particular area and this particular portion of the propeller blade is made to cavitate. Thus it reduces the thrust generated by the propeller and slight increase the torque demand. 


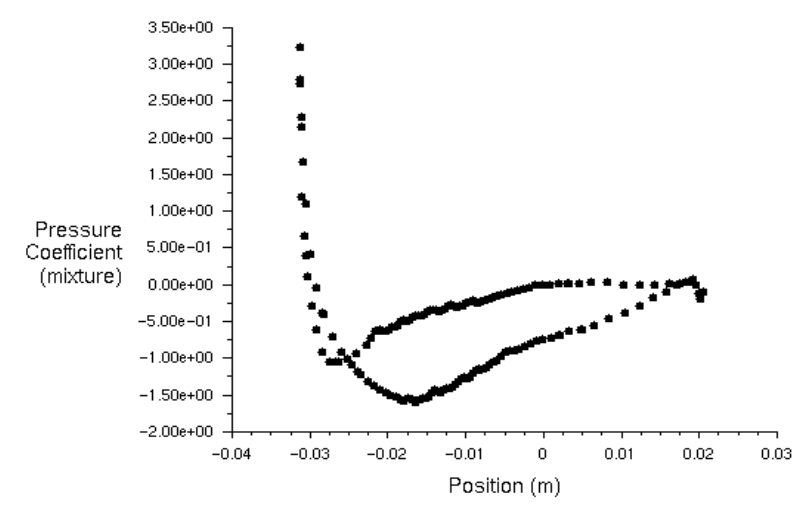

Fig. 18: Pressure distribution graph at $\mathrm{J}=\mathbf{0 . 8 4 7}$ and $\mathrm{r} / \mathrm{R}_{\mathrm{p}}=\mathbf{0 . 2 6 4}$

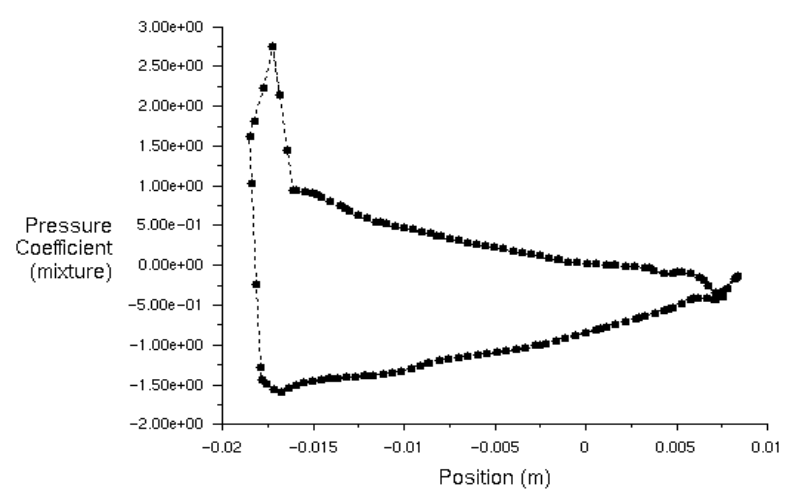

Fig. 19: Pressure distribution graph at $\mathrm{J}=\mathbf{0 . 8 4 7}$ and $\mathrm{r} / \mathrm{R}_{\mathrm{p}}=\mathbf{0 . 8 8 0}$

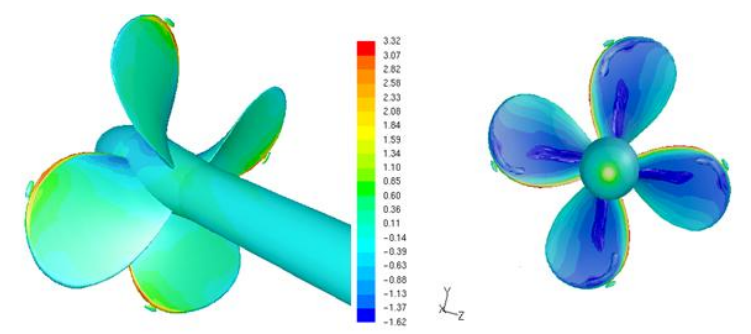

Fig. 20: Contour of pressure coefficient in cavitation
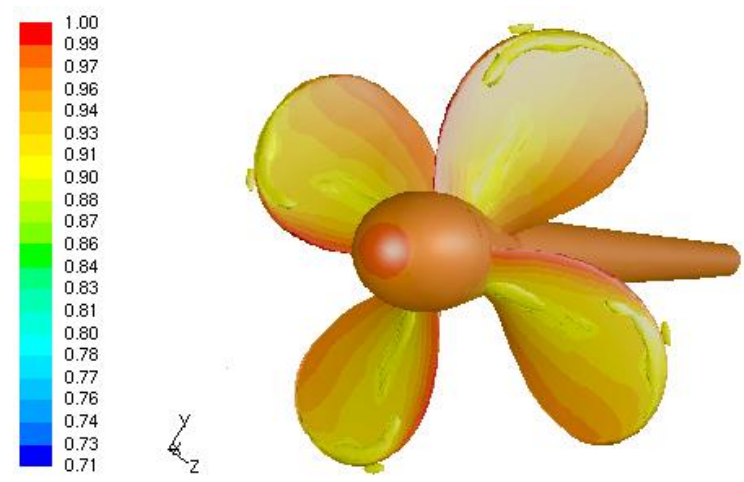

Fig. 21: Contours of Volume fraction

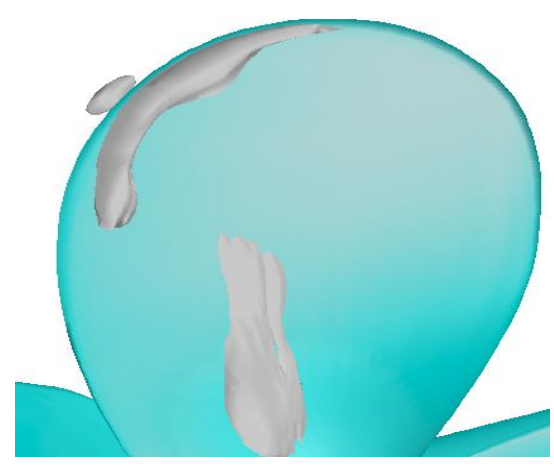

(a)

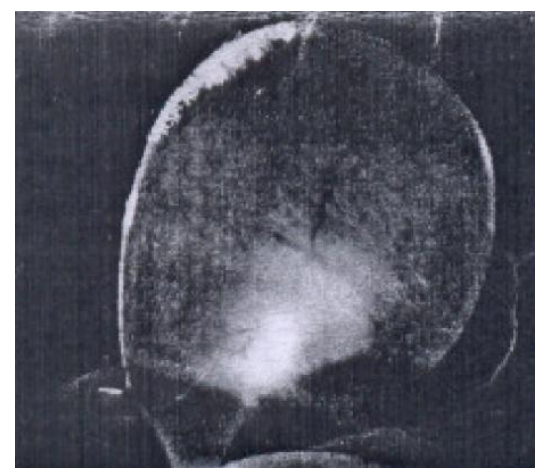

(b)

Fig. 22: Development of cavities on propeller blade and comparison between CFD and experiments [1]

(a) Simulations (b) Experiments [1]

\section{CONCLUSIONS}

Based on foregoing analysis it is concluded that

- Computation results are in good agreement with experimental findings [1].

- Commercial CFD code likes Fluent 6.3 can solve open water characteristics of propeller with reasonable accuracy. Estimations are very close to that off experimental results.

- $\quad$ CFD and commercial code Fluent 6.3 can be used to solve advanced phenomena like cavitation. In view of the complexities involved, the present result of cavitation and their agreement with experiment is very encouraging. However more detailed studies and validations of cavitating propeller for different cavitation numbers are to be taken up to establish reliability of CFD for this type of studies.

\section{ACKNOWLEDGMENTS}

Authors expresses their sincere thanks to Sri S.V.Rangarajan,Sc'H' Director NSTL,Visakhapatnam and sri PVS Ganesh Kumar,Sc'G' NSTL,Visakhapatnam for his continuous support and guidance for publishing this paper.

\section{REFERENCES}

[1] Salvatore, F., Testa, C., Ianniello, S. and Pereira, F. 2006. Theoretical modeling of unsteady cavitation and induced noise, INSEAN, Italian Ship Model Basin, Rome, Italy, Sixth International Symposium on Cavitation, CAV2006, Wageningen, The Netherlands. 
[2] Chang, B.1998. Application of CFD to P4119 propeller, $22^{\text {nd }}$ ITTC Propeller RANS/Panel Method Workshop, France.

[3] Sanchez-Caja, A. 1998. P4119 RANS calculations at VTT, 22 ${ }^{\text {nd }}$ ITTC Propeller RANS/Panel Method Workshop, France.

[4] Bernad, S. 2006. Numerical analysis of the cavitating flows, Center of Advanced Research in Engineering Sciences, Romania Academy, Timisoara Branch, Romania.

[5] Senocak, I. and Shyy, W. 2001. Numerical simulation of turbulent flows with sheet cavitation, Department of Aerospace Engineering, Mechanics and Engineering Science, University of Florida, Florida.

[6] Sridhar, D., Bhanuprakash, T. V. K., and Das, H. N. 2010. Frictional resistance calculations on a ship using CFD, Int. J. of Computer Applications, Vol. 11, No.5, pp 24-31.

[7] Salvatore, F., Greco, L. and Calcagni, D. 2011. Computational analysis of marine propeller performance and cavitation by using an inviscid-flow BEM model, Second International Symposium on Marine Propulsors, smp'11, Hamburg, Germany.

[8] Bertetta, D., Brizzolara, S., Canepa, E., Gaggero, S. and Viviani, M. 2012. EFD and CFD characterization of a CLT propeller, Int. J. of Rotating Machinery, Vol. 2012, Article ID 348939, 22 pages, doi:10.1155/2012/348939.

[9] Zhi-feng ZHU and Shi-liang FANG, 2012. Numerical investigation of cavitation performance of ship propellers, J. of Hydrodynamics, Ser. B, Vol. 24, No. 3, pp 347-353.

[10] Pereira, F., Salvatore, F., and Di Felice, F. (2004). Measurement and modeling of propeller cavitation in uniform inflow, J. of Fluids Engineering, Vol. 126, pp 671-679.

[11] Pereira J. C. F. and Sequeira, A. 2010. Propeller-flow predictions using turbulent vorticity-confinement, V European Conference on Computational Fluid Dynamics, ECCOMAS CFD 2010, Lisbon, Portugal. 